\title{
DEVELOPMENT AND STANDARDIZATION OF AUDITORY LOW-FREQUENCY WORD LISTS IN HINDI
}

\author{
Animesh Barman, Prashanth Prabhu, Vijaya Kumar Narne, Spoorthi Thammaiah, \\ Niraj Kumar Singh, Mahima Gupta
}

Department of Audiology, All India Institute of Speech and Hearing, Manasagangothri, Mysore, India

Corresponding author: Prashanth Prabhu, Department of Audiology, All India Institute of Speech and Hearing, Manasagangothri, Naimisham Campus, Mysore, Karnataka, India 570006, e-mail: prashanth.audio@gmail.com

\begin{abstract}
Background: Conventionally, it is believed that high-frequency auditory information is important for speech understanding. This is only partly true, as recent studies have demonstrated the importance of low-frequency information. This research was taken up to develop, standardize, and validate auditory low-frequency word lists in Hindi, an Indian language.

Material and methods: The first phase of the study involved collection of bisyllabic words followed by verification by a native linguist. Words were then short-listed based on familiarity ratings given by 10 adult native speakers; those words were recorded and the best recorded words selected through subjective and objective analysis. Then, using Fast Fourier Transform and $k$-means clustering, words with more energy below $1.5 \mathrm{kHz}$ were isolated. Finally, equally difficult 10 word lists were generated by obtaining psychometric function curves. Finally, lists were administered on 40 adult normal hearing participants at 0 , 10, 20, and $30 \mathrm{~dB}$ sensation level (SL). The word list was also standardized on 100 Hindi speakers at $40 \mathrm{~dB}$ SL.
\end{abstract}

Results: Results showed a similar trend of increase in speech identification scores with increase in SL across all lists except list 4. During the final phase, developed lists were validated on 10 simulated low-frequency cochlear hearing loss participants. Hearing loss was simulated using Matlab and National Institute for Occupational Safety and Health (NIOSH) software. Results of validation revealed that auditory low-frequency word lists were sensitive enough to tap the speech understanding difficulty in the simulated condition.

Conclusions: The developed word lists can be used clinically to assess communication ability in individuals with rising hearing loss. The word lists also have the potential to assess the performance after amplification provided to individuals with rising hearing loss.

Key words: Hindi $\bullet$ bisyllabic word lists $\bullet$ speech identification scores $\bullet$ frequency loss $\bullet$ hearing loss simulation $\bullet$ psychometric equivalence

\section{ELABORACIÓN Y ESTANDARIZACIÓN DE LISTAS DE PALABRAS DE BAJA FRECUENCIA PARA EL IDIOMA HINDI}

\section{Resumen}

Introducción: Comúnmente se cree que la información codificada en las altas frecuencias es fundamental en el proceso de la comprensión del habla. Sin embargo, en vista de los presentes estudios, los cuales demuestran una importancia considerable de la información codificada en las bajas frecuencias, este argumento es solo en parte verdad. En el marco de los estudios descritos en la presente publicación, se han elaborado, estandarizado y normalizado listas de palabras de baja frecuencia para el idioma hindi, una de las lenguas indoarias.

Materiales y métodos: En la primera fase de los trabajos de investigación, se agruparon palabras bisílabas, verificadas por un lingüista hablante nativo del idioma. A continuación, en base a la valoración del conocimiento de las palabras, realizada por 10 hablantes nativos del idioma, dicha lista se acortó y gravó, y las mejores versiones de la grabación se eligieron según una valoración subjetiva y objetiva. El siguiente paso fue aislar palabras por debajo de $1,5 \mathrm{kHz}$ mediante transformada rápida de Fourier y algoritmo K-means. En la fase final se crearon 10 listas de palabras del mismo grado de dificultad según curvas psicométricas y, por consiguiente, cada una de las listas se usó para examinar a 40 personas con la audición normal, aplicando un nivel percepción de estímulos sonoros de 0, 10, 20 y 30 dB SL. Dichas listas se sometieron a una estandarización que abarcó 100 hablantes del idioma hindi, presentándoles las palabras a un nivel de $40 \mathrm{~dB}$ SL.

Resultados: En todas las listas, salvo la lista no. 4, se ha observado una mejora similar del grado de identificación del habla, proporcional al aumento de la percepción de estímulos sonoros (SL). En la etapa final, las listas creadas se normalizaron en un grupo de 10 pacientes con pérdida coclear, utilizando el programa Matlab y el software del Instituto Nacional para la 
Seguridad y Salud Ocupacional (National Institute for Occupational Safety and Health, NIOSH). En el proceso de normalización se ha demostrado que en condiciones experimentales las listas de palabras de baja frecuencia son suficientemente sensibles para poder identificar las dificultades en la comprensión del habla.

Conclusiones: Las listas elaboradas podrán utilizarse en la evaluación clínica de habilidades comunicativas en pacientes con una pérdida de audición progresiva. Pueden también servir para evaluar a estas personas tras la aplicación de audífonos.

Palabras clave: hindi • listas de palabras bisílabas • identificación del habla • pérdida de audición de alta frecuencia • simulación de pérdida auditiva • equivalencia psicométrica

\section{РАЗРАБОТКА И СТАНДАРТИЗАЦИЯ НИЗКОЧАСТОТНЫХ СЛОВЕСНЫХ СПИСКОВ ДЛЯ ЯЗЫКА ХИНДИ}

\section{Изложение}

Введение: Считается, что информация, кодирующаяся в высоких частотах, имеет существенное значение в процессе понимания речи. Однако в свете актуальных исследований, в которых было доказано немалое значение информации, кодирующейся в низких частотах, данное утверждение является верным только частично. В рамках ислледований, рассмативающихся в настоящей публикации, были разработаны, стандартизированы и нормализированы низкочастотные словесные списки для языка хинди - одного из новоиндийских языков.

Материал и методы: На первом этапе исследовательских работ были собраны двусложные слова, проверенные языковедом, который является естественным носителем языка. Затем на основании оценки знания слов, сделанной десятью естественными носителями языка, список был сокращён и записан в аудиоформате, причём самые лучшие версии записи были выбраны на основании объективной и субъективной оценки. Следующим шагом было выделение слов с энергетическим зарядом менее 1,5 кГц на основании быстрого преобразования Фурье и метода k-средних. На конечном этапе было создано 10 словесных списков похожего уровня сложности на основе психометрических кривых, после чего каждый из списков использовался для исследования 40 человек в слуховой норме на уровне восприятия 0, 10, 20 и 30 дБ SL (sensation level). Данные списки подверглись стандартизации, охватывающей 100 пользователей языка хинди, которым слова подавались на уровне 40 дБ SL.

Результаты: За исключением списка 4, в случае всех остальных списков наблюдалось похожее улучшение уровня идентификации речи, пропорциональное росту уровня восприятия (SL). На последнем этапе созданные списки были нормализированы в группе 10 пациентов с тугоухостью, вызванной повреждениями структур внутреннего уха, с использованием программы Matlab и программного обеспечения Национального института охраны труда (NIOSH). В процессе нормализации было обнаружено, что в условиях исследования низкочастотные словесные списки являются достаточно чувствительными, чтобы обнаружить сложности с пониманием речи.

Выводы: Разработанные списки могут использоваться в клинической оценке коммуникативной компетентности пациентов с нарастающей тугоухостью. Они также могут служить для её оценки после установки слуховых аппаратов у таких людей.

Ключевые слова: хинди • списки двухсложных слов • идентификация речи • высокочастотная потеря слуха • симуляция тугоухости • психометрическая эквивалентность

\section{OPRACOWANIE I STANDARYZACJA NISKOCZĘSTOTLIWOŚCIOWYCH LIST SŁOWNYCH DLA JEZYKA HINDI}

\section{Streszczenie}

Wprowadzenie: Powszechnie uważa się, że informacje kodowane w wysokich częstotliwościach są istotne w procesie rozumienia mowy. Jednak w świetle obecnych badań, w których wykazano niemałe znaczenie informacji kodowanej w niskich częstotliwościach, twierdzenie to jest tylko po części prawdziwe. W ramachbadań opisywanych w niniejszej publikacji opracowano, wystandaryzowano oraz znormalizowano niskoczęstotliwościowe listy słowne dla języka Hindi, jednego z języków nowoindyjskich.

Materiał i metody: Na pierwszym etapie prac badawczych zestawiono słowa dwusylabowe, zweryfikowane przez językoznawcę, będącego rodzimym użytkownikiem języka. Następnie - na podstawie oceny znajomości słów, dokonanej przez 10 rodzimych użytkowników języka - listę tę skrócono i nagrano, przy czym najlepsze wersje nagrania wybrano na podstawie oceny subiektywnej i obiektywnej. Kolejnym krokiem było wydzielenie słów o ładunku energetycznym poniżej 1,5 kHz na podstawie szybkiej transformaty Fouriera i algorytmu k-średnich. W końcowym etapie stworzono 10 list słownych o podobnym poziomie 
trudności na podstawie krzywych psychometrycznych, a następnie każdą z list wykorzystano do badania 40 osób w normie słuchowej na poziomie odczucia $0,10,20$ oraz $30 \mathrm{~dB}$ SL. Listy te poddano standaryzacji, obejmującej 100 użytkowników języka Hindi, którym słowa podawano na poziomie $40 \mathrm{~dB}$ SL.

Wyniki: Za wyjątkiem listy 4, w przypadku wszystkich list zaobserwowano podobną poprawę stopnia identyfikacji mowy, proporcjonalną do wzrostu poziomu odczucia (SL). W końcowym etapie, stworzone listy znormalizowano w grupie 10 pacjentów z ubytkiem ślimakowym, z wykorzystaniem programu Matlab i oprogramowania Państwowego Instytutu Bezpieczeństwa i Higieny Pracy (NIOSH).W procesie normalizacji wykazano, iż w warunkach badania niskoczęstotliwościowe listy słowne są wystarczająco czułe, by wykryć trudności z rozumieniem mowy.

Wnioski: Opracowane listy mogą być wykorzystane w klinicznej ocenie sprawności komunikacyjnej u pacjentów z narastającym niedosłuchem.Mogą także służyć do jej oceny po zastosowaniu aparatów słuchowych u tych osób.

Slowa kluczowe: Hindi • listy słów dwusylabowych • identyfikacja mowy • ubytek wysokoczęstotliwościowy • symulacja niedosłuchu • równoważność psychometryczna

\section{Background}

Hearing loss can emerge due to a variety of causes. Auditory signs and symptoms of different hearing disorders are almost unique. One sign that helps us identify the cause of a hearing problem is the shape of the audiogram. The losses in the audiogram are usually different for different disorders: certain disorders lead to a flat pattern, while others result in more loss at either low or high frequencies. Many studies report the estimate of prevalence of different configurations of hearing loss over the years. Margolis and Saly [1] reported that the sloping configuration was the most common $(40 \%)$, followed by flat $(16 \%)$, peaked (5\%), rising (3\%), other (2\%), and trough (1\%) configurations. As per the findings of the National Speech and Hearing Survey, carried out on 38,568 children between grade 1 to 12 , around $2 \%$ had low-frequency hearing loss and 3-4\% had high-frequency hearing loss [2]. Rabinowitz et al. [3] reported that among 2526 young adults (ages $17-25$ years), $16 \%$ had high-frequency hearing loss and 5\% had low-frequency hearing loss. In elderly individuals (age $>60$ years), the prevalence of different hearing loss configurations was found to be $29 \%$ flat, $6 \%$ rising, $36 \%$ gradually sloping, and $29 \%$ sharply sloping [4]. On inspecting these results, it can be observed that across ages there is a small but considerable proportion of population which has low-frequency loss.

Conventionally, it is believed that high-frequency sounds are more important for speech understanding, and thus more focus has been given to perception of speech by individuals with high-frequency hearing loss $[5,6]$. Researchers have attempted to develop assessment tools for testing high-frequency speech perception difficulties and the research focus has even extended towards developing new concepts and technologies for better rehabilitation of individuals with high-frequency loss [5-8]. However, the concept that only high-frequency sounds contribute to better speech understanding is just partly true, as there are studies which support the importance of low frequencies in speech perception $[9,10]$.

Jin and Nelson [9] studied the effect of low to mid frequency information on sentence recognition and found that those listeners with higher degree of hearing losses in the low frequencies performed poorer in understanding interrupted sentences. Also, low to mid frequency hearing thresholds accounted for most of the variability in perception of speech in the presence of noise (a masker) for listeners with hearing impairment. Based on these findings, they concluded that low-frequency information within speech plays an important role in segregating speech from competing background noise. Providing low to mid frequency additional amplification to people with severe-to-profound sensorineural hearing loss has been shown to improve their speech comprehension abilities [11]. Gantz et al. [10] studied the benefit of a hybrid cochlear implant on 21 patients and found a significant improvement in speech understanding in noise over standard cochlear implant participants. They concluded that low-frequency hearing is important for speech perception, especially in noise.

Further, it has been reported that the importance of frequency for speech perception is language-dependent. That is, in certain languages more weighting is given to low frequencies in understanding speech. Avilala et al. [12] examined the effect of filtering of monosyllables and words on speech perception in 30 normal adults. They reported that in Kannada, a south Indian language, the low-pass cut-off frequency for words at which $70 \%$ speech identification scores were obtained was $1200 \mathrm{~Hz}$, which is slightly lower than the cut-off frequency $(1500 \mathrm{~Hz})$ reported for English words [13].

Owing to the diversity and the varying underlying pathology of auditory disorders, it is reasonable to speculate that speech perception of different clinical populations is different. One set of patients may have good speech perception abilities at high frequencies while another may be at lower frequencies. Factors underlying their varying capacities may be the degree of hearing loss, configuration of hearing loss, or the underlying pathology itself. For instance, Prabhu et al. [14] studied the speech perception abilities of individuals with auditory dys-synchrony and found that speech understanding scores was poorer for low-pass filtered words in comparison to unfiltered words. They also recommended the use of low-pass filtered words as a tool for accurately assessing speech perception difficulties in individuals with auditory dys-synchrony.

Speech is highly redundant owing to the simultaneous transmission of information in several ways. Thus, a hearing loss involving only a part of frequency range may go 
undetected if standard speech tests are used. Conventionally, phonetically balanced (PB) word lists are used to assess speech understanding abilities. Hindi PB word lists were developed by De [15]. The usefulness of these tests has been validated for individuals with a flat hearing loss. Thus, use of these tests for determining communication problems may not be accurate if an individual has more loss at low or high frequencies. Several test materials have been developed in Indian languages that can assess individuals with high-frequency hearing loss. Some of these include high-frequency word list in Hindi [16], Kannada [17], English [18], Tamil [19], and Telugu [20]. These tests are now used to assess an individual's perception of high-frequency speech information. However, to date few attempts have been made to develop speech materials for assessing a patient's ability to perceive low-frequency information. In addition, auditory low-frequency word lists are needed to select appropriate hearing devices/management options for individuals with low-frequency hearing loss. Such a word list may also be useful to assess hearing disorders with varying speech perception abilities for low and high-frequency speech information.

The objectives of the study were to develop auditory lowfrequency word lists in Hindi and to obtain speech identification scores. The objectives were also to establish equalized multiple lists and standardize the developed word lists. An attempt was also made to check the validity of the developed word lists by administering them under a simulated rising hearing loss condition.

\section{Material and methods}

The present study aimed to develop auditory low-frequency word lists in Hindi (an Indo-Aryan language of India). For this purpose the study was conducted in three phases: development of the auditory low-frequency word lists; standardization of the test materials developed; and determining the usefulness of the test materials.

\section{Phase I. Development of the auditory low-frequen- cy word lists}

This phase was subdivided into four stages: collection of words and obtaining familiarity ratings; recording and selection of the best recorded words; separating words with dominant low-frequency energy; and finally generating word lists with equal difficulty levels.

\section{Collection of words and obtaining familiarity ratings}

Bisyllabic Hindi words were collected from different sources (common newspapers, magazines, books). The words were collected irrespective of the energy concentration of phonemes across frequencies. Those words were verified for the presence of any script errors and correct categorization as bisyllabic words by a native linguist. Then, the corrected word list was given to 10 adult native Hindi language speakers to rate the words on a 5-point familiarity rating scale. The ratings used were 'unfamiliar,' 'less familiar', 'familiar', 'more familiar', and 'most familiar'. If the meaning of a word was not known to the native speaker, they were asked to rate it as 'unfamiliar' or 'less familiar'. If the speaker had heard a word before, it was asked to be rated as 'less familiar', and if the speaker had heard the word for the first time then the rating they were asked to give it was 'unfamiliar'. They were told to rate a word as 'familiar' if the speaker was aware of the meaning but used it rarely. Speakers were instructed to give 'more familiar' ratings to words used often, and 'most familiar' ratings to words which they used very often in day-to-day conversation. Familiarity ratings from all participants were compiled and analyzed. The words rated familiar, more familiar, or most familiar by $70 \%$ of the participants were considered and the rest of the words were excluded from the list.

\section{Recording of words and selection of best recorded words}

Selected words were recorded in a sound treated room using Computerized Speech Lab Model 4500, an input/output recording device for personal computers by KayPentax. Recording was done using a 16-bit analogue to digital converter at a sampling rate of $44.1 \mathrm{kHz}$. A unidirectional dynamic microphone (Shure SM-48) was used for recording and was kept at about $6 \mathrm{~cm}$ from the speaker's mouth.

Initially, 15 of the selected words were recorded from 3 native adult male fluent speakers of Hindi. As the mean fundamental frequency of male speakers is lower than female speakers, the male voice was used for recording the words. The recordings were then given to 4 adult native speech and hearing professionals with normal hearing for judging the most appropriate voice to record the entire list. Judges were asked to rate the voice based on voice quality, clarity, and naturalness on a 3-point rating scale (poor, fair, and good). The voice which received the highest score was selected and that person's voice was used for recording all the words selected.

The selected familiar words were recorded with the selected speaker's voice in 5 separate sessions. Each word was recorded five times in a clear and monotonous voice. Out of five recordings, the first and the last were removed and only the middle three underwent subjective and objective analysis for selection of the best recorded words. Praat software (version 5.3.03) was used for objective analysis. Firstly, words were subjectively analyzed and rated by an experienced audiologist for clarity of the utterance, presence of any intonation patterns, and audible background noise. Out of the three repetitions of each word, the best rated recordings - free of background noise, clear, and monotonous - were considered. Further, among those same recordings, one with visible pitch and formants observed using Pratt software was finally selected during objective analysis. Those words for which all five repetitions were eliminated during subjective and objective analysis (if they did not satisfy any of the criteria) were re-recorded, and the entire analysis procedure repeated. A sample spectrogram of one of the words in Hindi is shown in Figure 1. All the selected audio samples of words were edited to remove silence and saved in.wav format. These wave files were equalized to a root mean square (RMS) amplitude of $-26 \mathrm{~dB}$ prior to further processing. Matlab 7.9.0 (Mathworks; Natick, MA, USA) was used for editing and for offline analysis. 


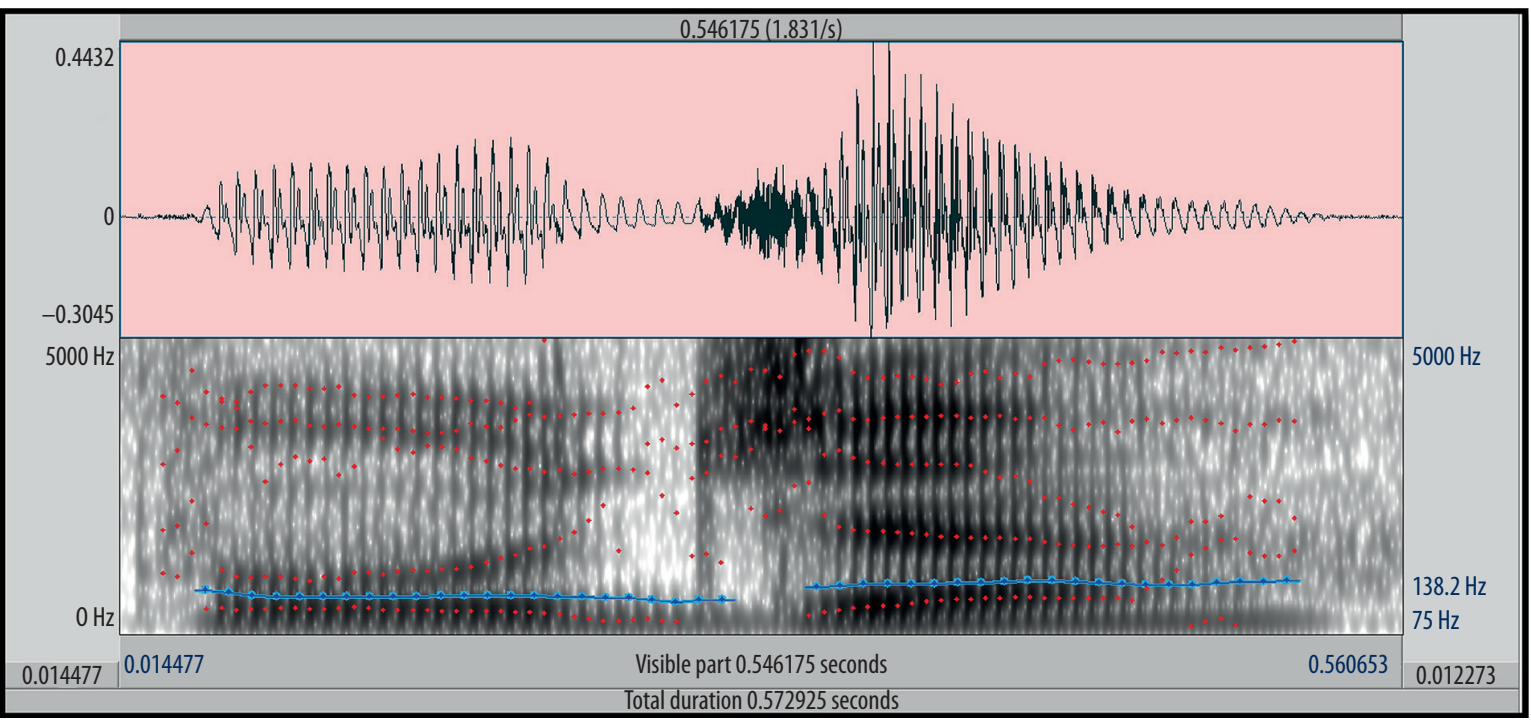

Figure 1. Spectrogram of Hindi word/pooja/showing formants (red dotted lines) and pitch (blue solid line)

\section{Separating words with dominant low-frequency energy}

Using Matlab R2009b, a Fast Fourier Transform (FFT) was carried out for all words. The FFT was done with a Hanning window and a narrowband slice of 0.03 seconds. The amplitude of energy below and above $1.5 \mathrm{kHz}$ was calculated for all the words individually. These amplitudes were used to obtain amplitude ratios: the ratio of energy below $1.5 \mathrm{kHz}$ to that above $1.5 \mathrm{kHz}$. Amplitude cut-off ratios for Hindi words was 1.8. Further, considering these amplitude ratios, $k$-means clustering was applied to all the words. In $k$-means clustering, the total data is divided into a number of clusters with its nearest mean. Here, clustering resulted in the formation of 2 clusters, one with words having dominant low-frequency energy and the other with the rest of the words. Thus, a targeted low-frequency cluster of words was isolated.

Using Matlab, a long-term average speech spectrum (LTASS) was obtained for the clusters of low-frequency words. This was achieved by performing a Fast Fourier analysis on 2048-point Hamming-windowed samples, and then computing the average magnitude spectrum across samples. This was carried out to verify the correct categorization of words as low-frequency dominant. To further ensure that the lists did not include words with more high-frequency energy, the words were also subjected to phonemic analysis. During this analysis, attempts were made to eliminate the words having consonants considered as high-frequency in Hindi. Thus, the word list was further short-listed making sure there was a predominance of low-frequency energy.

\section{Generating word lists with equal difficulty}

All the auditory low-frequency words were then presented to 25 adult native speakers with normal hearing at 5 different sensation levels (ref: pure tone average). Sensation levels (SLs) considered were $+0,+4,+8,+12$, and $+16 \mathrm{~dB}$. A calibrated dual channel diagnostic audiometer (Maico 53) was used for screening participant's hearing and also to present the words. The recorded speech material was played back using Matlab. The signal was routed through a personal computer to the audiometer and presented through Sennheiser HDA-200 headphones.

All the auditory low-frequency words were presented at one sensation level (SL) for each participant, and data was collected from 5 participants at each SL. The participants were asked to write down the words, and speech identification (SI) scores were calculated using the following formula:

\section{SI Score $=\frac{\text { Total number of correct responses }}{\text { Total number of words presented }} \times 100$.}

The speech identification scores obtained from the participants at each SL were averaged and tabulated. Based on the averaged scores at all SLs, psychometric functions were derived for all the words using Matlab. The mean sensation level (where 50\% SI scores occurred) and mean slope of the psychometric functions were obtained. Words falling within \pm 1.5 standard deviations of the overall mean and slope were accepted. These words were used to make the final word lists of 25 words each. However, lists were not phonemically balanced as high-frequency consonants were removed.

For constructing an equalized list, firstly 25 words were randomly selected from the available word pool. For each list, the mean SL where 50\% scores occurred and the mean slope was calculated. The mean SL and slope were compared with the overall mean SL and slope of the low-frequency word pool obtained initially. If the mean value was within \pm 1.5 standard deviations, then the list considered was selected. If not, then another set of 25 words were randomly selected and this procedure was repeated. As a result, finally 10 Hindi word lists of 25 words each were formed. The word lists developed were recorded on a CD-R using a personal computer at 16 bits and $44.1 \mathrm{kHz}$ sampling frequency. 
Table 1. List of Hindi-speaking individuals with simulated rising cochlear $\mathrm{HL}$

\begin{tabular}{ccccc}
\hline & Age (years)/gender & Ear & Pure tone average (dB HL) & SIS (\%) \\
\hline 1 & $18 / \mathrm{M}$ & $\mathrm{R}$ & 10 & 100 \\
\hline 2 & $20 / \mathrm{F}$ & $\mathrm{R}$ & 11.25 & 100 \\
\hline 3 & $18 / \mathrm{F}$ & $\mathrm{L}$ & 10 & 96 \\
\hline 4 & $19 / \mathrm{M}$ & $\mathrm{R}$ & 12.5 & 100 \\
\hline 5 & $20 / \mathrm{F}$ & $\mathrm{L}$ & 1.5 & 96 \\
\hline 6 & $22 / \mathrm{F}$ & 6.25 & 100 \\
\hline 7 & $25 / \mathrm{M}$ & $\mathrm{L}$ & 15 & 100 \\
\hline 8 & $19 / \mathrm{F}$ & $\mathrm{R}$ & 5 & 100 \\
\hline 9 & $28 \mathrm{~F}$ & $\mathrm{~L}$ & 7.5 & 100 \\
\hline 10 & $21 / \mathrm{M}$ & $\mathrm{L}$ & 11.25 & \\
\hline
\end{tabular}

SIS - Speech Identification Scores; L - left, R - right.

\section{Phase II. Standardization of the test material}

The developed test materials in Hindi were standardized by obtaining the SI scores from 100 adult native Hindi speakers at $40 \mathrm{~dB}$ SL. All participants were in the age range of 18 to 55 years. It was ensured that all the participants had hearing thresholds within $15 \mathrm{~dB} \mathrm{HL}$ at octave frequencies between $250 \mathrm{~Hz}$ and $8000 \mathrm{~Hz}$ and SI scores above $90 \%$ [15]. The participants had type 'A' tympanograms with acoustic reflexes present bilaterally. Also, all the participants had bilateral TEOAEs present and more than $60 \%$ score on speech perception in noise test at $0 \mathrm{~dB}$ signal to noise ratio.

A calibrated dual channel diagnostic audiometer (Maico 53) was used for pure tone and speech audiometry. The recorded speech material was played back using Matlab. The signal was routed through a personal computer to the audiometer and presented through Sennheiser HD200 headphones.

\section{Establishing psychometric function curves}

The word lists developed in Phase I were used to obtain SI scores at $0,+10,+20$, and $+30 \mathrm{~dB}$ SL (ref: pure tone average). 40 normal hearing participants were tested at each SL to establish the psychometric function curve. To avoid an ear effect, for 20 individuals the words were presented to the right ear and for the remaining 20 participants the left ear was used for testing. An open set response in the form of verbal repetitions was obtained from all participants. The SI scores at each SL were averaged, tabulated, and analyzed.

\section{Phase III. Determining the usefulness of the test} material

Due to the unavailability of Hindi-speaking patients with low-frequency cochlear hearing loss at the centre where data was collected, a rising cochlear hearing loss was simulated on normal hearing individuals using Matlab and National Institute for Occupational Safety and
Health (NIOSH) Hearing Loss Simulator software (version 3.0.12151). The categorization of rising type was made based on the classification given by Lloyd and Kaplan [21]. The details of Hindi-speaking individuals with simulated cochlear hearing loss are shown is Table 1.

Using NIOSH software, moderate rising low-frequency hearing loss was simulated for all participants by manually setting the hearing thresholds for octave frequencies between $125 \mathrm{~Hz}$ to $8000 \mathrm{~Hz}$. Using Matlab software, reduced frequency selectivity was added to the hearing loss simulation. This was done by splitting the input signal into 13 frequency bands, and processing the envelope in each band so as to create reduced frequency selectivity in a normal ear that would resemble those produced in an impaired ear with cochlear loss and the bands were then recombined. The detailed procedure followed to generate spectrally-smeared output has been described by Moore and Glasberg [22]. The procedure included calculating a short-term spectrum using a Hamming window and an FFT. Following that, the spectrum was smeared and then transformed back to the time domain using an inverse FFT. Finally, waveforms obtained from overlapping analysis frames were added to produce the final output.

Hearing thresholds were obtained for octave frequencies between 250 to $8000 \mathrm{~Hz}$. The pure tone average (PTA) was an average of thresholds at $0.5,1,2$, and $4 \mathrm{kHz}$. Speech identification scores were obtained using phonetically balanced word lists available in Hindi [15]. The standardized auditory low-frequency word lists (10 lists in Hindi) were presented to all the participants at $30 \mathrm{~dB}$ SL (ref. PTA). The presentations were randomized, both in terms of order of words and lists. SI Scores were obtained using the formula given in Phase I. Scores were then averaged and tabulated for all the lists separately. To explore the difference in performance between normal hearing individuals and individuals with simulated rising cochlear hearing loss, data was analyzed using SPSS software (version 20). 


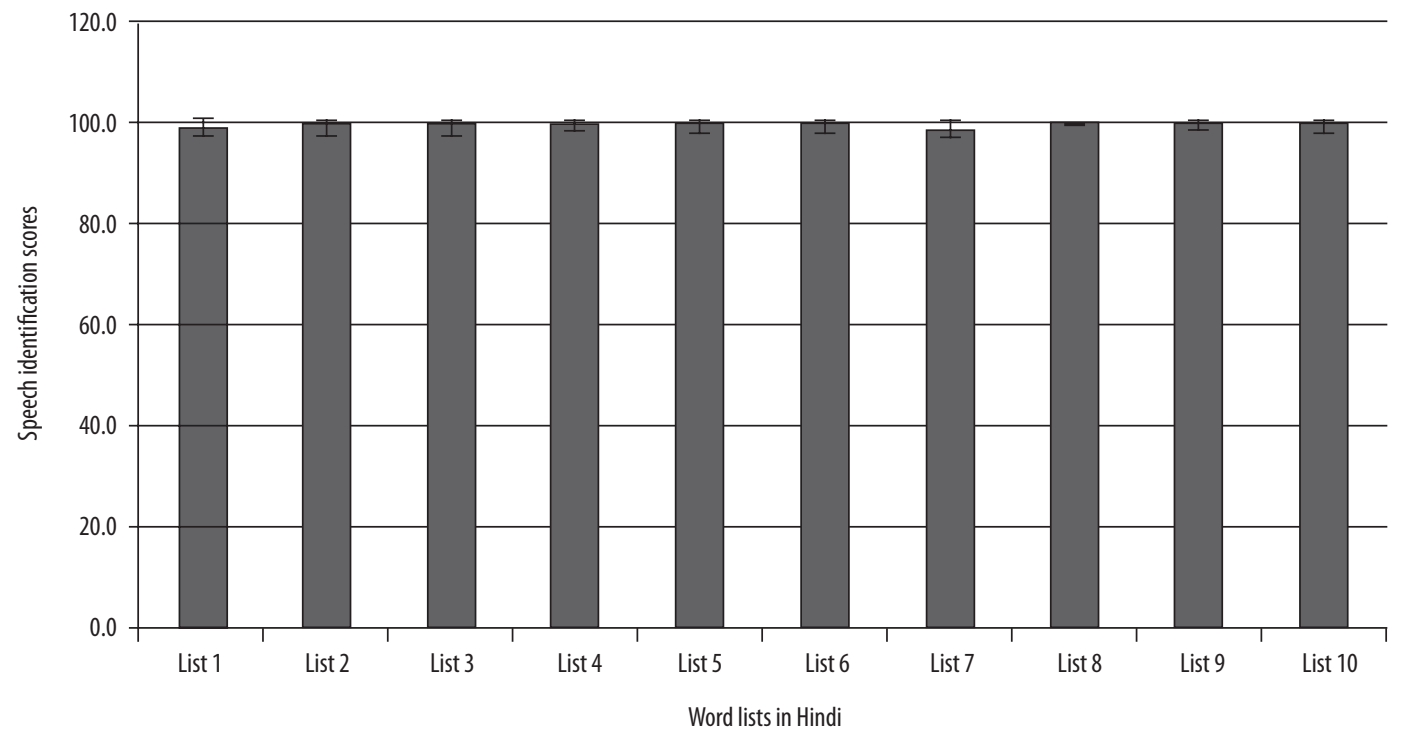

Figure 2. Mean and SD of SI scores obtained for word lists in Hindi at $40 \mathrm{~dB}$ SL

\section{Results}

The study was carried out in three phases: 1) Development of the auditory low-frequency word lists; 2) Standardization of the word lists developed; and 3) Validating the usefulness of the test material developed. Results of all the phases are provided separately and analyzed using SPSS (version 20).

Development of the auditory low-frequency word lists

\section{Collection of words and obtaining familiarity rating}

One of the important factors to be considered while developing speech material is word commonness or familiarity [23]. With this in mind, a total of 2012 and 2090 bisyllabic words were collected from common sources in Hindi. It was then evaluated by a native linguist for script errors and correct categorization as bisyllabic words. Further, a 5-point familiarity rating scale ('unfamiliar,' 'less familiar', 'familiar', 'more familiar', 'most familiar') was used to get familiarity ratings for all words by 10 native adult speakers. 'Less familiar' and 'unfamiliar' words were eliminated and the words left over were 1319.

\section{Selection of the best recorded words}

The 1319 Hindi bisyllabic words were recorded five times using the best speaker as judged by five professionals. After perceptual analysis by an audiologist and an objective analysis using Praat software, 1319 best recorded bisyllabic words were selected.

\section{Separating words with dominant low-frequency energy}

The above-mentioned 1319 recorded words were subjected to fast Fourier transformation (FFT) to obtain amplitude ratios having a cut off frequency of $1.5 \mathrm{kHz}$. $k$-mean clustering was done to identify the low-frequency and high-frequency words based on an amplitude ratio of 1.8. Based on $k$-mean clustering, 850 words were rated to be low-frequency words. To verify the difference in energy distribution across frequencies, the long-term average speech spectrum (LTASS) was executed on the clusters of 850 words grouped as low frequency. To further ensure that the lists did not include phonemes with high-frequency energy, efforts were made to remove words with consonants considered predominantly as high frequency, leaving 721 words.

\section{Generating word lists with equal difficulty levels}

Using this 721 low-frequency word cluster, speech identification (SI) scores were obtained from 25 adult native speakers with normal hearing at sensation levels of +0 , $+4,+8,+12$, and $+16 \mathrm{~dB}$. The SI scores were calculated, averaged, and tabulated. Based on the average scores at all SLs, psychometric functions were obtained for all the words. From the psychometric function curves, the mean level for a $50 \%$ SI score was obtained and the slope of function was derived. Words falling within \pm 1.5 standard deviations from the mean and the slope for the psychometric functions were isolated. This resulted in a selection of 691 Hindi words.

Using this word pool, final Hindi word lists were formed. These word lists were generated such that all lists had equal difficulty levels. Equal difficulty was verified by first randomly selecting 25 words from the 691 Hindi words, and generating psychometric function curves for those words (as mentioned in the methods). Finally, a total of 10 lists in Hindi were developed. Hence, these word lists can be considered psychometrically equivalent word lists. In addition, the frequency of occurrence of low-frequency words was similar to the published literature on Hindi [24,25]. Appendix 1 provides details of the word lists. 


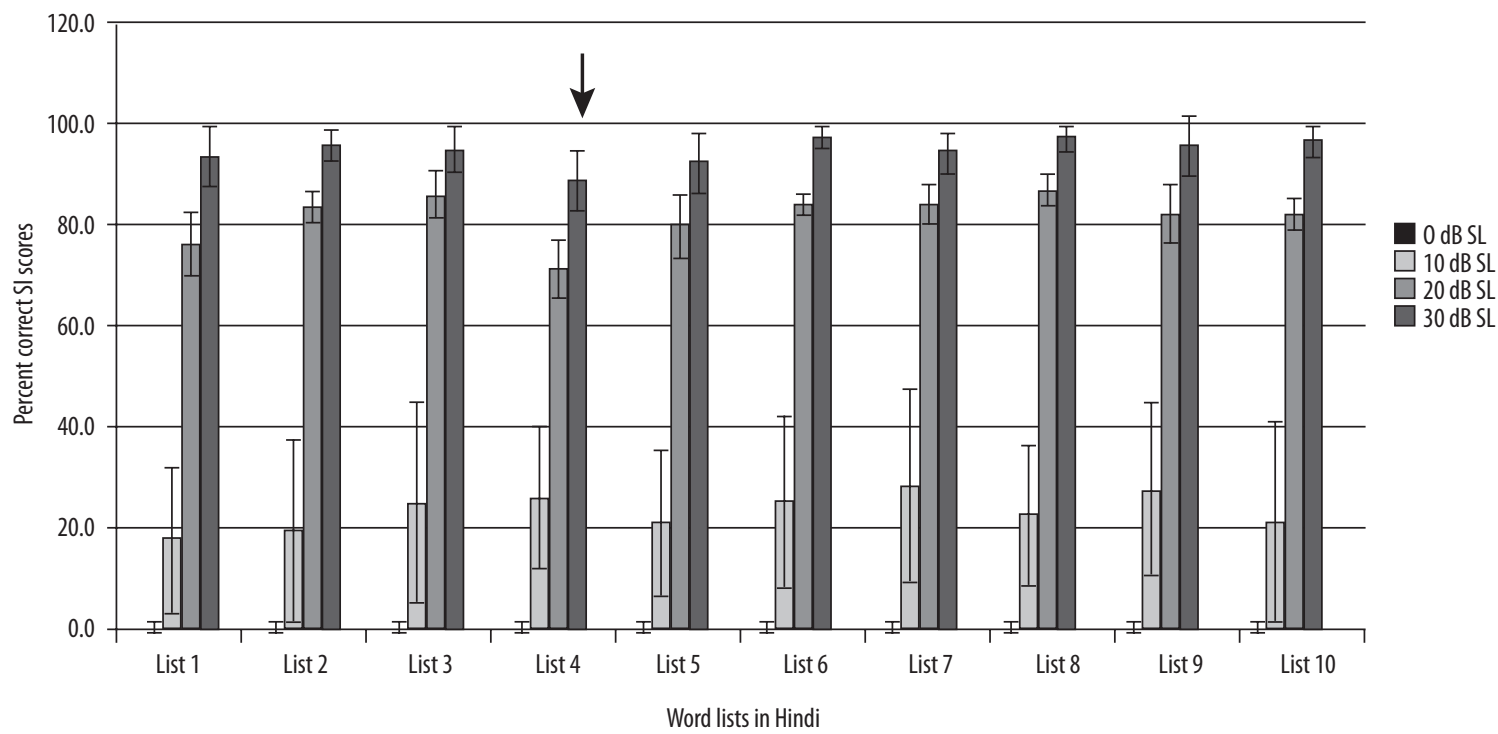

Figure 3. Mean SI scores and standard deviations of all lists across SLs. Black arrow highlights the finding that SI scores for list 4 at 20 and $30 \mathrm{~dB}$ SLs were lower compared to other lists

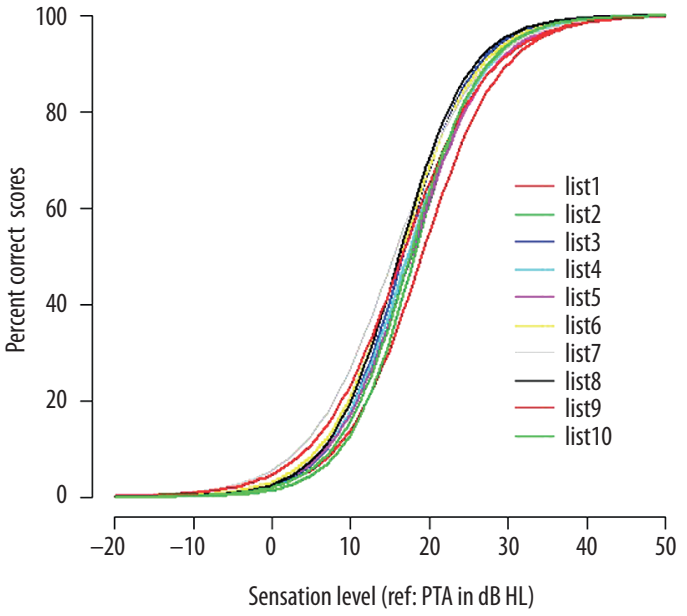

Figure 4. Psychometric function curves across SLs for low-frequency Hindi lists

\section{Standardization of the test material}

The mean and SD of SI scores obtained at $40 \mathrm{~dB}$ SL in 100 individuals with normal hearing for 10 lists in Hindi are shown in Figure 2. The SI scores were averaged for all the participants and lists were considered as repeated variables. Thus, repeated measures ANOVA was done to compare differences across lists. The results showed that there was no significant difference across lists $[F(9,891)=34.93$, $p>0.05$ ] at $40 \mathrm{~dB}$ SL.

SI scores were also obtained from 40 participants for the final lists across $0,+10,+20$, and $+30 \mathrm{~dB}$ SL (ref. PTA). Figure 3 depicts mean SI scores and standard deviations for all the lists across SLs.
To inspect equality of lists, psychometric function curves were obtained for SI scores across SLs in Hindi (Figure 4). It was found that, except for one list, all the other lists followed the same trend in difficulty across SLs. In psychometric function curves of Hindi, it can be noted that $100 \%$ scores were reached at about 30 to $40 \mathrm{~dB}$ SL.

The scores obtained at different SLs and number of lists was considered as repeated variables. The mean scores obtained for the word lists were compared across SLs for all the lists using repeated measures ANOVA. It was noticed that there was a significant difference between SLs $[F(3,27)=302.42$, $p<0.001]$ and even across lists $[F(9,81)=4.474, p<0.001]$. Interaction between lists and SLs was also found to be significant $[F(27,243)=2.483, p<0.001]$. Post hoc analysis was done using Bonferroni correction. Results revealed that scores across SLs were significantly different from one another, with scores increasing from $0 \mathrm{~dB}$ SL to $30 \mathrm{~dB}$ SL $(p<0.001)$. At $10 \mathrm{~dB}$ SL, there was no significant difference between SI scores across lists, while at $20 \mathrm{~dB}$ SL, list 4 was found to be significantly different from list 2 and 8 . Even at $30 \mathrm{~dB}$ SL, SI scores of word list 4 were significantly different from lists $2,6,8$, and $10(p<0.05)$.

\section{Determining the usefulness of the test material}

To determine the usefulness of the test material, the lists were administered on 10 Hindi-speaking individuals under simulated condition resembling rising cochlear hearing loss. Figure 4 shows the mean and standard deviation of SI scores between normals and simulated low-frequency cochlear hearing loss (SLCHL).

Mixed ANOVA was carried out to find if there was any significant difference in SI scores between groups across word lists. In mixed ANOVA, groups were considered as between-subject factors and lists as a within-subject factor. The main effects showed a significant difference between 


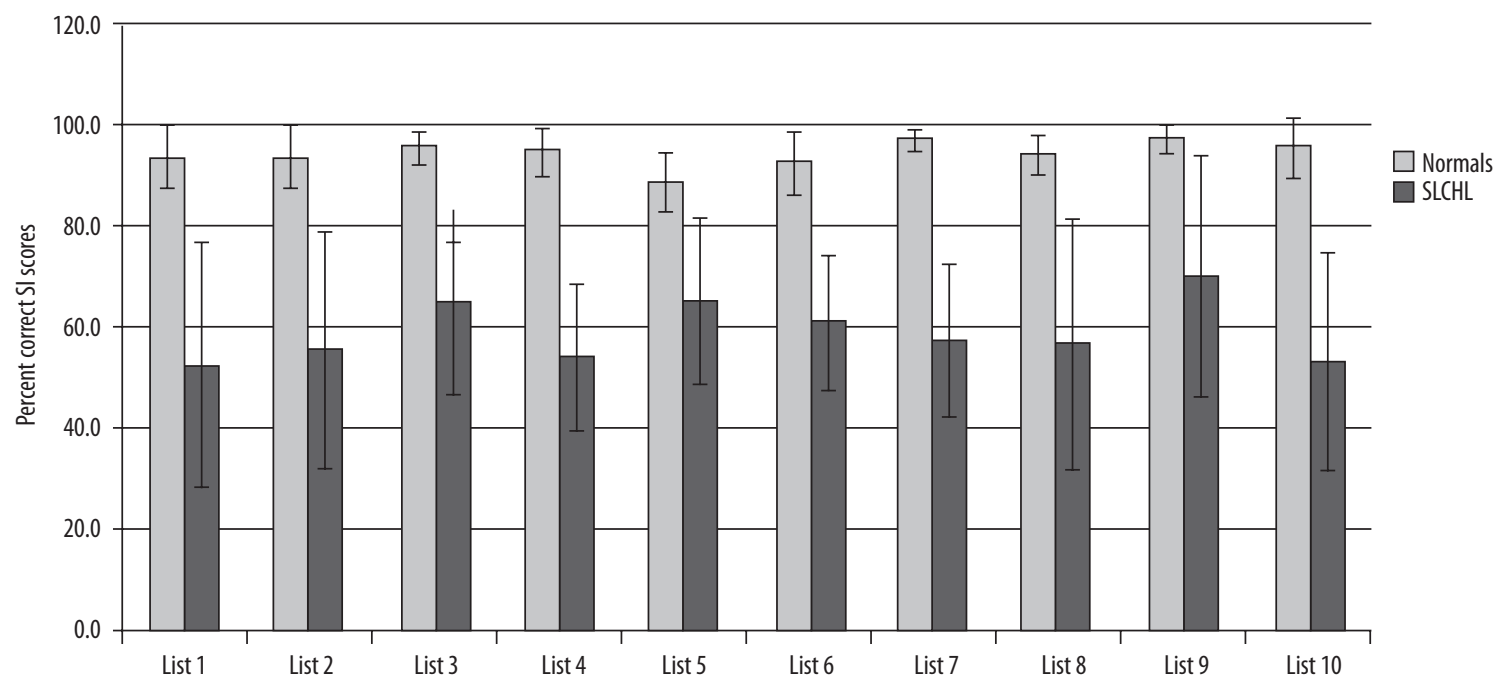

Figure 5. Mean and SD of SI scores of normals and simulated low-frequency cochlear hearing loss (SLCHL) group in Hindi

lists $[F(9,162)=2.064, p<0.05]$ and between normal and simulated hearing impaired group $[F(1,18)=50.076$, $p<0.001]$. Also, significant interaction was seen between lists and group $[F(9,162)=2.188, p<0.05]$. Post hoc analysis using Bonferroni correction showed that only list 4 was significantly different from list 3 and 6.

\section{Discussion}

This study resulted in development and standardization of auditory low-frequency word lists in Hindi. In total, 10 auditory low-frequency word lists in Hindi were developed. In the psychometric function curves of Hindi, it was observed that $100 \%$ scores were reached at $30 \mathrm{~dB}$ SL. This is congruent with earlier reports where maximum speech identification scores were obtained in normal hearing individuals at 30 to $40 \mathrm{~dB}$ SL [26]. One of the important considerations during development of any speech material for testing is that alternative forms of testing should be equivalent; that is, they should produce comparable results [27]. The conventional way of obtaining equivalency between developed word lists is phonemic or phonetic balancing. However, recent research in the field has shown that the impact of phonetic or phonemic balancing is questionable [28]. Thus, to develop word lists which produce equivalent results, a procedure which considers psychometric function curves was carried out. Hence, these developed word lists can be considered psychometrically equivalent word lists.

These lists are not phonetically or phonemically balanced, as all the phonemes do not appear in the lists. In the Hindi psychometric function curves, almost $100 \%$ scores are reached around $30 \mathrm{~dB}$ SL. This is congruent with earlier reports by Gold et al. [26]. Out of the 10 word lists, one list (list 4) in Hindi was found to vary significantly from the other lists. The probable reason for such a finding was poorer SI scores of list 4 at 20 and $30 \mathrm{~dB}$ SL (Figure 3), suggesting higher difficulty compared to other lists. Hence, it is preferable not to use this list for clinical purposes. Instead, the words in this list may be used as practice material.

The present study also validated the list on simulated lowfrequency cochlear hearing loss individuals. It is clear from Figure 3 that, across lists, normal hearing individuals outperform individuals with SLCHL. The word lists were found to be difficult for individuals with simulated rising cochlear hearing loss, thus validating the usefulness of the developed lists. Thus, these standardized word lists can be recommended for use on clinical population to gauge their difficulty in understanding low-frequency information. Studies may also undertake validation of this speech material on other clinical population.

\section{Conclusions}

The present study attempted to develop a standardized auditory low-frequency word list in Hindi. It resulted in the development of 10 Hindi word lists. The study used psychometric function curves to determine equivalent lists. The word lists were standardized and were also validated on simulated low-frequency cochlear loss. The developed word lists can be used clinically to assess communication ability in individuals with rising hearing loss. Similarly, these word lists have the potential to assess the performance after amplification provided to individuals with rising hearing loss. 
Appendix 1. Hindi low-frequency word lists.

\begin{tabular}{|c|c|c|c|c|c|c|c|c|c|c|}
\hline & List 1 & List 2 & List 3 & List 4 & List 5 & List 6 & List 7 & List 8 & List 9 & List 10 \\
\hline 1 & बहू & अलाप & बैरा & बदल & आगा & अंजाम & आत्मा & अगर & बंधा & आला \\
\hline 2 & बंजर & अटक & बंधक & बाधा & बंधु & बाडा & अंदाज & अनार & भवन & अधर \\
\hline 3 & बारह & बहा & बंदर & बौना & बेदाग & बहाव & बयान & बाहर & डाबर & अंदर \\
\hline 4 & बयाँ & बेलन & बवाल & भरत & भुवन & बंधन & बेटा & बाजू & दौरा & अटल \\
\hline 5 & भाडा & भाग्य & भालू & दायर & दमन & बेताब & बुआ & बाला & गौरव & बाबुल \\
\hline 6 & दाता & बौंरा & भजन & डंडा & दातुन & दीला & दावा & बामन & जरा & बना \\
\hline 7 & दादी & बूरा & भुजा & धीमा & दवा & धीरज & धावा & बढाव & जंगल & भाला \\
\hline 8 & देखा & दादी & डाका & गदर & धंधा & गवाह & डोरी & भला & मैदा & भानु \\
\hline 9 & ढोलक & डाला & दामाद & गोकुल & धारा & गुलाल & गला & बूढा & मकर & भाग्य \\
\hline 10 & घुमाव & दीपक & धमाल & गुण & गाजर & जटा & गुरू & दमा & मरण & भाई \\
\hline 11 & जहाज & गेहूँ & जवान & जंतु & घातक & जतन & जवान & धारण & मौका & भोंपू \\
\hline 12 & लावा & घूँघट & लागत & लगाम & गोदाम & लालन & जमाव & गुना & नरम & बोली \\
\hline 13 & लाया & जागो & माता & लखिा & गोता & लहर & महा & जलिा & पगार & दवात \\
\hline 14 & मंजन & जोडा & मावा & मेवा & जंतर & लेखक & नाला & मादक & पैंदा & दोना \\
\hline 15 & नदी & लेखन & नयाब & नवल & जवाब & लोहार & नादान & मैय्या & पलंग & गंगा \\
\hline 16 & नारद & मंजा & नवाब & पाना & लगान & मजार & नकद & मरू & पंजा & लाली \\
\hline 17 & नेता & मेला & नखिलि & पकड & मंदा & नाता & पराग & पीपल & प्रकार & लगाव \\
\hline 18 & नधित & मुराद & नयिम & पलट & मात्रा & पालन & रहन & पौधा & राहू & मजाक \\
\hline 19 & नपुिण & मुरूगा & पागल & रानी & मलिाप & पांया & राणा & प्रबंध & राजा & मुकर \\
\hline 20 & पहाड & पर्वत & पावन & तंबू & पडाव & पीपा & रेणु & तांगा & तालू & परे \\
\hline 21 & पहल & पूरण & राहत & त्रगुण & परख & पूजा & ताना & तमाम & तरुण & पवन \\
\hline 22 & पोखर & प्रहार & रेखा & उपज & पुकार & पुर्जा & तोता & ताऊ & तीखी & तलब \\
\hline 23 & प्रदान & तडप & रेला & वजन & तपन & ताई & वेतन & वार्ता & तीतर & तनु \\
\hline 24 & रुकाव & तरुण & तालाब & युवा & उधार & वहन & वधि & वधू & यात्रा & तीखा \\
\hline 25 & ताजा & तवाह & वविाद & युवक & वादा & यात्री & यदा & वदिति & युगल & तुला \\
\hline
\end{tabular}

\section{References:}

1. Margolis RH, Saly GL. Asymmetric hearing loss: definition, validation, and prevalence. Otol Neurotol, 2008; 29(4): 422-31.

2. Hull FM, Mielke PW, Timmons RJ, Willeford JA. The national speech and hearing survey: Preliminary results. ASHA, 1971; 13(9): 501-9.

3. Rabinowitz PM, Slade MD, Galusha D, Dixon-Ernst C, Cullen MR. Trends in the prevalence of hearing loss among young adults entering an industrial workforce 1985 to 2004. Ear Hear, 2006; 27(4): 369-75.

4. Gates GA, Couropmitree NN, Myers RH. Genetic associations in age-related hearing thresholds. Arch Otolaryngol Head Neck Surg, 1999; 125(6): 654-59.

5. Stelmachowicz PG, Pittman AL, Hoover BM, Lewis DE, Moeller MP. The importance of high-frequency audibility in the speech and language development of children with hearing loss. Arch Otolaryngol Head Neck Surg, 2004; 130(5): 556-62.
6. Gardner HJ. Application of a high-frequency consonant discrimination word list in hearing-aid evaluation. J Speech Hear Disord, 1971; 36(3): 354-55.

7. Noble W, Sinclair S, Byrne D. Improvement in aided sound localization with open earmolds: observations in people with high-frequency hearing loss. J Am Acad Audiol, 1998; 9(1): 25-34.

8. Pascoe DP. Frequency responses of hearing aids and their effects on the speech perception of hearing-impaired subjects. Ann Otol Rhinol Laryngol, 1975; 84(5 pt 2 Suppl 23): 1-40.

9. Jin S, Nelson P. Interrupted speech perception: the effects of hearing sensitivity and frequency resolution. J Acoust Soc Am, 2010; 128(2): 881-89.

10. Gantz BJ, Turner C, Gfeller KE, Lowder MW. Preservation of hearing in cochlear implant surgery: Advantages of combined electrical and acoustical speech processing. Laryngoscope, 2005;115(5): 796-802. 
11. Turner C, Brus S. Providing low-and mid-frequency speech information to listeners with sensorineural hearing loss. J Acoust Soc Am, 2001; 109(6): 2999-3006.

12. Avilala VKY, Prabhu P, Barman A. The effect of filtered speech on speech identification scores of you normal hearing adults. J All India Inst Speech Hear. 2010; 29(1): 115-19.

13. Bornstein SP, Wilson RH, Cambron NK. Low- and high-pass filtered Northwestern University Auditory Test No. 6 for monaural and binaural evaluation. J Am Acad Audiol, 1994; 5(4): 259-64.

14. Prabhu P, Avilala V, Barman A. Speech perception abilities for spectrally modified signals in individuals with auditory dyssynchrony. Int J Audiol, 2011; 50(5): 349-52.

15. De NS. Hindi PB list for speech audiometry and discrimination test. Ind J Otolaryngol, 1973; 25(2): 64-75.

16. Ramachandra P. High Frequency Speech Identification Test for Hindi and Urdu speakers. University of Bengaluru; 2001.

17. Kavitha EM. High Frequency Kannada Speech Identification Test (HF-KST). University of Mysore; 2002.

18. Sudipta KB. High Frequency-English Speech Identification Test (HF-ESIT). University of Mysore; 2006.

19. Sinthiya KM. High Frequency Speech Identification Test in Tamil. University of Mysore; 2009.

20. Ratnakar YV. High Frequency Speech Identification Test in Telugu. University of Mysore; 2010.
21. Lloyd LL, Kaplan H. Audiometric Interpretation. Baltimore MD: University Park Press; 1978.

22. Moore BC, Glasberg BR. Simulation of the effects of loudness recruitment and threshold elevation on the intelligibility of speech in quiet and in a background of speech. J Acoust Soc Am, 1993 Oct;94(4): 2050-62.

23. Hirsh IJ, Davis H, Silverman SR, Reynolds EG, Eldert E, Benson RW. Development of materials for speech audiometry. J Speech Hear Disord, 1952; 17(3): 321-37.

24. Jain C, Narne VK, Singh NK, Kumar P, Mekhala M. The development of Hindi Sentence Test for speech recognition in noise. Int J Speech Lang Pathol Audiol, 2014; 2(2): 86-94.

25. Ramakrishna BS, Nair KK, Chiplunkar VN, Atal BS, Ramachandran V, Subramanian R. Some aspect of the relative efficiencies of Indian languages. Banglaore: Indian Institute of Science; 1992.

26. Gold S, Lubinsky R, Shahar A. Speech discrimination scores at low sensation levels as a possible index of malingering. J Aud Res, 1981; 21(2): 137-41.

27. Roeser RJ, Valente M, Hosford-Dunn H. Audiology Diagnosis. New York: Thieme; 2011.

28. Martin FN, Champlin CA, Perez DD. The question of phonetic balance in word recognition testing. J Am Acad Audiol, 2000; 11(9): 489-93. 